\title{
The Effect of Audit Tenure and Firm Size on Financial Reporting Delays
}

\author{
Rina Yuliastuty ${ }^{1}$ Asmara and Rini Situanti
}

\begin{abstract}
:
The timeliness of financial reporting is an important characteristic of accounting information, since historical information will affect the economic decision-making process made by users of financial statements.
\end{abstract}

This study aims to identify and analyze the effect of audit tenure and firm size on audit delay and its impact on timeliness. The population in this study are consumer goods companies listed on the Indonesia Stock Exchange (IDX) for the period 2014-2016.

The sampling technique used in this research is purposive sampling. Based on predetermined criteria, the sample consisted of 30 companies with observations for three years is 90 observations. The data collected is secondary data in the form of audited financial statements of the firms using a documentary method via the Indonesia Stock Exchange.

The method of analysis used in this research is the outer model and the inner model through SmartPls 3.0 program. The results of this study indicate that: audit of tenure and firm size have no effect on audit delay and timeliness, and audit delay significantly influences timeliness.

For further research authors suggest testing the financial reporting timeliness with different objects, i.e., by adding other variables that are expected to affect the financial reporting timeliness.

Keywords : Timeliness, audit delay, audit tenure, firm size.

\footnotetext{
${ }^{1}$ Department of Auditing, Universitas Mercu Buana, E-mail: rinaasmara@ymail.com
} 


\section{Introduction}

In the last few years, business activity in Indonesia has been growing rapidly, and this is marked by the increasing number of companies going public and being listed on the Indonesia Stock Exchange (IDX). In 2010, the number of companies listed on BEI was 422, in 2011, increased to 442 in 2012, it increased again to 463, and increasing again in 2013 and 2014 to 486 and 509 respectively. In 2015 the number reached 525 and in 2016 the number amounted to 539 companies. Companies going public and listed on the Indonesia Stock Exchange (BEI) are required to submit annual financial reports audited by public accountants in accordance with the Decree of the Chairman of the Capital Market and Financial Institution Supervisory Agency Number KEP-346/BL/2011. Annual financial statements should be published so that investors, as an external party, can measure and assess firm performance. Therefore, the firm must provide information that is informative, transparent and available in the financial statements.

The financial statements are a form of corporate management accountability by management of the resources given to them that are useful for decision making (Arifa, 2013). Timely financial reporting is needed by internal and external companies that go public. According to Sa'adah (2013), the financial statements should be finished and published as soon as possible so as not to affect their capacity to influence the decision-making of the users. Companies going public are expected not to delay the presentation of financial statements so as not to reduce the benefits that the information could bring. The perceptions of the usefulness of the financial statements is based on the speed of publication (Suryanto and Thalassinos, 2017).

The length of time taken to complete the financial statements audit is one of the factors that have an impact in affecting the fast publication of financial reports, and this condition is called audit delay. Audit delay is the gap of audit time, that is, the time required by the auditor to produce audit reports on the performance of a firm's operation (Puspitasari, 2014). A publication delay resulting from an audit delay will cause a negative market reaction. The information presented will contain good news and bad news that can affect investment decision- making. This information (good or bad) will adversely affect both the firm and the public accounting firm. Therefore, auditors are required to reduce audit delay to eliminate any bad image that may be associated with the firm or the public accounting firm (Grima et al., 2017).

Tenure audits may affect the financial reporting timeliness. Audit tenure or audit engagement period is the time when the firm or issuer uses audit services in the same KAP for a certain period. Studies conducted by Ratnaningsih (2016), Distianingsih (2017), Anggreni and Latrini (2016) found a relationship between audit tenure with audit delay and financial reporting timeliness. There is a difference in research conducted by Praptika and Rasmini (2016) which states that the length of time the audit assignment takes does not affect audit delay. The length of the term of the restricted audit is deemed very important for both internal and external parties to 
maintain the independence of auditors in performing their duties. This has been regulated in Government Regulation No. 20 of 2015 on the practice of public accountants as stipulated in Article 11 paragraph (1) stating that the provision of audit services to historical financial information on an entity by a Public Accountant shall be limited to a maximum of five years, consecutive (Suryanto, 2014; 2016).

Another factor suspected to affect audit delay and financial reporting timeliness is firm size. Total firm assets are used to measure firm size. In this study, total assets refer to total current assets, fixed assets and investment and advances including intangible assets. The results of the study conducted by Che-Ahmad and Shamharir (2008) explains that firm size has a significant effect on audit delay. But research conducted by Ahmad and Anuar (2014) found no significant effect between audit delay and firm size. Enofe et al. (2013) and Pham et al. (2014) state that there is a negative relationship between firm-size and audit report lags. A further difference was found in the study by Mukhtaruddin et al. (2015) which showed that firm size had a positive effect on audit report lag (Hapsoro and Suryanto, 2017).

Based on these studies one can see that there is inconsistency in research results. Given the importance of timely financial reporting for users of financial statements in decision-making, the purpose of this study is to re-examine the effect of audit tenure and firm size on audit delay and its impact on financial reporting timeliness.

\section{Theoretical, Informational, Empirical, and Methodological Ground of the Research}

Financial statements are prepared and interpreted for the benefit of management and other interested parties or anyone who has an interest in the financial data of the firm. The purpose of the financial statements is to provide information regarding the financial position, performance, and changes in the financial position of an entity that is beneficial to many users in economic decision-making. The firm is expected not to delay the presentation of financial statements that may affect the quality of the same financial statements (Yazid and Suryanto, 2016).

The demand for timeliness is stipulated in the Decision of the Chairman of the Capital Market and Financial Institution Supervisory Agency Number KEP-346 / BL / 2011 that states that annual financial statements must be submitted to Bapepam and LK and announced to the public no later than the end of the third month after the annual financial statement date. This is in line with the theory of compliance which encourages people to comply with the applicable regulations, as well as the firm that seeks to deliver the financial statements in a timely manner. In addition to a firm's obligation to deliver timely financial reports, it will also be very useful for users of financial statements.

To be able to publish financial reports in a timely manner, it needs to be effectiveness in the completion of the audit. The longer the auditor takes to complete 
the audit work, the longer the audit delay. If audit delay is longer, then the likelihood of a delay in the publication of the financial statements will be greater. This will affect the level of decision uncertainty based on published information. Audit tenure is one of the factors affecting audit effectiveness. In fact, empirical studies show that audit tenure works more effectively when there is a long engagement/relationship between the auditor and the client (Lee et al., 2009 in Dao and Pham, 2014). Kusumah and Daniel (2016) revealed that the longer the firm's engagement with the KAP, the shorter the audit report lag. This is because the characteristics of the firm and internal control system does not need to be reviewed again by public accountants. This opinion is supported by Dao and Pham (2014). Kusumah and Daniel (2016) found evidence that the shorter the audit engagement relationship, the longer the audit report lag. It is in line with Ratnaningsih's (2016) research, that audit tenure has a significant negative effect on audit delay. A supporting study conducted by Dewi and Ratnadi (2016) shows that there is an influence between audit tenure and the financial reporting timeliness. Therefore, we state the hypotheses as follows:

\section{H1: Audit tenure affects audit delay.}

H2: Audit tenure affects the financial reporting timeliness.

\subsection{Firm size, Audit Delay and Financial Reporting Timeliness}

Users of financial statements require analytical tools in making economic decisions, which are relevant, complete, accurate, and available as early as possible (Jeva and Ratnadi, 2015). Relevance of a financial statement can be obtained if the financial statements can be published in a timely manner. Relevance is not possible without timeliness, but timeliness ensures relevance.

According to Fahmi (2011), the financial statements presented in a timely manner will make the party more confident in the financial performance of the firm, so the parties associated with the firm will automatically feel satisfied in various associations with the firm. One of the factors that affects the quality of financial statements and the relevance of financial statements is timeliness. This can indicate the quality of financial statement information as well.

The importance of audit delay of a financial statement requires the auditor to complete his field work in a timely manner. On the other hand, auditing requires considerable time in identifying problems that occur within the firm and requires scrutiny in finding evidence. The size of the firm is one of the indicators that affect the period of completion of the audit of financial statements because the size of the firm is affected by the complexity of operations, variables and intensity of the firm's transaction that is in the form of total sales.

The size of the firm in this study is calculated as the total assets of the firm. Large companies are usually faster in delivering financial statements for several reasons. 
First, they have an abundance of resources, more accounting staff and sophisticated information systems and have a strong internal control system. Secondly, investors and regulators oversee big companies, they are more in the public spotlight, so they are under pressure to publish their financial statements on time to avoid speculation in the firm's stock trading (Owusu, 2000). Thus, the firm can accelerate the delivery of audited financial statements. This is supported by studies from Al-Ghanem and Hegazy (2011), Che-Ahmad and Shamharir (2008) and Hassan (2016) who found that a large firm does not have a long audit delay. Therefore, we state the hypotheses as follows:

H3: Firm size influences audit delay.

H4: Firm size affects the financial reporting timeliness.

\subsection{Audit delay and financial reporting timeliness}

The timeliness of completing the audit reflects the amount of time that an auditor needs to perform an audit of a firm's financial statements, that can be affected by the number of auditors in charge, and the number of hours required, including overtime. The delay in completing the audit report will keep stockholders suspended from their share transactions. So, audit delay greatly affects the financial reporting timeliness of companies that are being audited. The longer the audit delay, the longer the firm takes to publish its financial statements to the public, and vice versa. Therefore, we state the hypothesis as follows:

\section{H5: Audit delay affects the financial reporting timeliness.}

Based on the description of variables, the framework of thinking conducted by researchers in this study can be described as follows:

Figure 1. Conceptual Framework

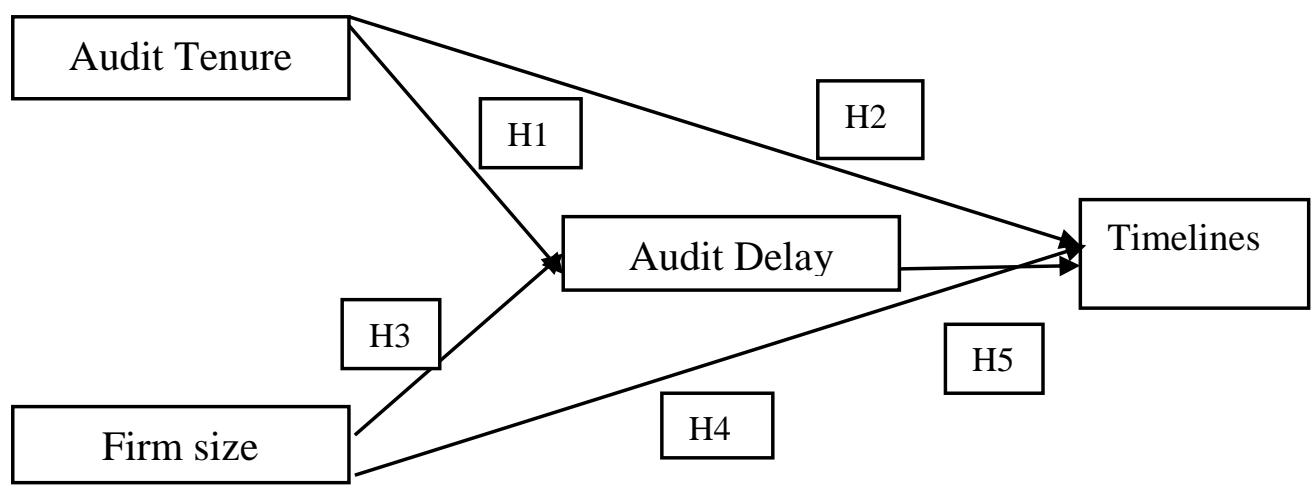




\subsection{Methodological grounds of the research}

The design used in this study is a causal research that aims to test the hypothesis concerning the effect of exogenous variables on the endogenous variables. The financial reporting timeliness shall be measured by counting the number of days from the date indicated in the independent auditor's report to the date of the publication of the financial statements by the ratio measurement scale. The delay audit variable shall be measured by the number of days from the closing date of the fiscal year to the date indicated by the independent auditor and the measurement scale. The nominal measurement scale for the audit tenure variable is measured by the dummy variable with the first year of engagement beginning with the number 1 and coupled with one for subsequent years. The ratio is the measurement scale for the size of the firm viewed with the total amount of assets that use in total assets. The outer model was performed to assess the validity and the reliability of the model. The Cronbach alpha was used for the indicator block, made for 90 observations, to ensure that the research instrument used was good.

The results of the test in Table 1 show the measuring instrument used to measure each variable - financial reporting timeliness, audit delay, audit tenure, and valid firm size (all loading factors $>0.6$ ). While the reliability testing of each research variable shows that every research variable is reliable (Cronbach aplha $>0.6$ ), it explains that each measuring instrument is suitable for measuring each variable and consistent to collect research data.

Table 1. Summary of measurement scale

\begin{tabular}{llll}
\hline Construct/measurement & $\begin{array}{l}\text { Factor } \\
\text { loading }\end{array}$ & $\begin{array}{l}\text { Composite } \\
\text { Reliability }\end{array}$ & $\begin{array}{l}\text { Cronbach's } \\
\text { alpha }\end{array}$ \\
\hline Financial reporting timeliness & 1,000 & 1,000 & 1,000 \\
Audit Delay & 1,000 & 1,000 & 1,000 \\
Audit Tenure & 1,000 & 1,000 & 1,000 \\
Firm size & 1,000 & 1,000 & 1,000 \\
\hline
\end{tabular}

The data analysis method used was SEM (Structural Equation Modeling) with SmartPLS 3.0 program. SEM is a statistical technique that allows testing of a series of relationships simultaneously. Relationship is the double link of several independent and bound variables. Before performing hypothesis testing, it is necessary first, to test the model used as a prerequisite.

Inner model testing aims to predict correlation among latent variables, evaluated by looking at the percentage of variance described by looking at the R-square value for endogenous latent constructs. Stone (1974) and Geisser (1975) conducted tests to test predictive relevance, and average variance was extracted Fornell and Lercker (1981) in Ghozali and Latan (2015), as well as looking at the test of goodness of fit model. 


\section{Results}

The result of the R-square test shows that the variable 'financial reporting timeliness' is influenced by the exogenous variables in this study with 0.17 or $17 \%$, while $83 \%$ is explained by other variables outside those studied. The exogenous latitude influence model on audit delay has an R-square value of 0,025 or $2.5 \%$ which can be explained by construct variability in this research, while $97,5 \%$ is explained by other variables not included in this study.

The test results of goodness of fit model show that the proposed model fits well according to the data. The measurement used is Q-square, and the value of Q-square $>0$ indicating that the model has predictive relevance value. The result of predictive relevance is 0,19075 that is bigger than 0 (zero). This means that $19.07 \%$ of the variation of the endogenous variables is explained by the exogenous variables used. Thus, the model is said to belong to a relevant predictive model.

After the goodness of fit model is obtained, then hypothesis testing can be done. The following Table 2 is a summary of data processing to test the hypotheses.

Table 2. Result of hypothesis test

\begin{tabular}{lllll} 
Variable & $\begin{array}{l}\text { Original } \\
\text { Sample }\end{array}$ & $\begin{array}{l}\text { Standard } \\
\text { Deviation }\end{array}$ & T-Statistic & Hypothesis \\
\hline H1 : Audit Tenure --> Audit & $-0,131$ & 0,068 & 1,747 & Rejected \\
Delay & 0,060 & 0,091 & 0,633 & Rejected \\
H2 : Audit Tenure --> Timeliness & $-0,098$ & 0,057 & 1,772 & Rejected \\
H3 : Firm Size --> Audit Delay & 0,090 & 0,076 & 1,196 & Rejected \\
H4 : Firm Size --> Timelines & $-0,384$ & 0,064 & 5,602 & Accepted \\
H5 : Audit Delay --> Timeliness & & & & \\
\hline
\end{tabular}

From the result of $\mathrm{H} 1$ and $\mathrm{H} 2$ test, there is no effect of audit tenure with audit delay and financial reporting timeliness (t-statistic 1,747 and 0,633 ) both less than the $t$ table corresponding value 1,96, while $\mathrm{H} 3$ and $\mathrm{H} 4$ show that there is no effect of firm size with audit delay and speed of publication of financial report (t-statistic 1,772 and 1,196) less than t table 1,96. For H5 there is an influence between audit delay with speed of publication of financial report (t-statistic 5,602 > 1,96). From the test results, there is no consistency in the direction of interrelationships between variables formed between theory and practice.

\section{Discussion}

Based on the result of $\mathrm{H} 1$ test, it can be concluded that audit delay in consumer goods firms is not influenced by audit tenure time. This can be caused by an auditor who has a long assignment with client firm but not necessarily able to encourage the 
creation of good business knowledge. The results of this study are in line with the results by Rustiarini and Sugiarti (2013), Praptika and Rasmini (2016), but are in contrary to the research conducted by Ratnaningsih (2016). This is probably because every KAP will provide good services for its clients or because KAP attachment to its client does not affect audit delay. Another opinion expressed by Rustiarini and Surgiarti (2013) is that the assignment of auditors for a long time can cause those auditors to be less independent and professional in carrying out its duties. This of course makes the auditor not able to complete its obligations in a timely manner, thereby reducing the timeliness of the delivery of audited financial statements.

From the result of $\mathrm{H} 2$ test, it is found that the length of engagement with KAP does not improve the control function of the firm. This means that the contract between the firm and the auditor is inefficient and therefore it cannot realize the firm's goal of quality financial report submitted in a timely manner (Narayana and Yadnyana, 2017). The results of this study are in line with the research conducted by Krisnanda and Ratnadi (2017) and Narayana and Yadnyana (2017). However, they are in contrary to the research conducted by Jeva and Ratnadi (2015), Dewi and Ratnadi (2016) and Anggreni and Latrini (2016) stating that audit tenure affects the financial reporting timeliness. There is an understanding that cooperation between a firm and a KAP does not affect the speed of publication of an annual financial report. Susilawati et al. (2012) stated that the duration of cooperation between clients and KAP has no effect on audit delay, thus it can be concluded that the efficiency of an auditor in understanding all operational activities of a firm does not affect the speed of publication.

The result of $\mathrm{H} 3$ test explains that firm size does not have an impact on audit implementation. In other words, the size of the firm has not been able to guarantee the length and brevity of audit delay that will be experienced by a firm. The results of this study are in line with the results of research conducted by Haryani et al. (2014), Kowanda et al. (2016) and Wiryakriyana and Widhiyani (2017), but not in line with the research conducted by Puspitasari (2014). This is probably because the auditors carrying out the audit assignment are professional and meet the audit standards as set by the IAI, regardless of the size of the firm being audited (Subagyo, 2009). The potential for a longer audit delay in large firms is based on the view that the scope of the audit and the complexity of transactions at large firms will be wider than that of small firms, but this is not the case for consumer goods companies sampled in this study, which means that the size of consumer goods companies do not reflect the complexity in the application of audit procedures and the time required to complete the audit task.

The result of $\mathrm{H} 4$ test explains that the large or small scale of a firm has no effect on the acceleration of the delivery of financial statements, so variable size of the firm (size) cannot be a factor affecting the financial reporting timeliness (timeliness). The results of this study are in line with the research conducted by Sudaryono (2007) but are in contrary to the research conducted by Widati and Fina (2008) and Rambe et 
al. (2011). This is probably due to the fact that the larger the size of the firm makes the submission of financial statements slower. The greater the firm, the more transactions that occur within the firm. Therefore, the firm takes a longer time in processing these transactions, and it can cause companies to take longer to submit financial statements. But in this case, the size of consumer goods companies does not affect the financial reporting timeliness. Consequently, it can be concluded that the fast publication of financial statements does not depend on the size of the firm in consumer goods companies.

The result of $\mathrm{H} 5$ test illustrates that the faster the settlement time of the audit, the faster the publication of financial statements to the public. The audit delay variable in consumer goods companies can be one factor that affects the speed of financial reporting (timeliness). The results of this study are in line with the research conducted by Sudaryono (2007), stating that the timing of audit completion of financial statements affects the time of the announcement of audited financial statements. Another supporting study was conducted by Kurniawan (2015) which stated that audit delay influenced timeliness because the length of audit time would affect the timeliness in publicizing the financial statements.

\section{Conclusions and recommendations}

\subsection{Conclusions}

The financial statements are the cornerstone of today's business activities, requiring quality and relevant financial statements for its users. The speed of publication variable was developed because it is an important factor that can contribute to literature. The study found that there is no effect of audit tenure with audit delay and publishing speed, and firm size does not influence audit delay and publishing speed. Furthermore, it was found that audit delay influenced the speed of publication.

\subsection{Implication for practitioners}

The information obtained from the results of this study is expected to be useful for KAP and public accountants to show consideration regarding the practice of audit services, so efficiency and effective completion of audit services can be improved. The firm should provide relative information for the preparation and presentation of quality financial statements, thereby reducing audit delay.

\subsection{Limitations and suggestions for further research}

All studies have limitations, but they can also be used to offer suggestions for further researchers. First, this research used the consumer goods sector firms only. For further research the authors suggest using the whole industry of manufacture or other type of companies listed on the Stock Exchange. This study is limited to its variables only, and further research can add other exogeneous variables that are expected to 
influence audit delay and financial reporting timeliness. This research only used three fiscal year periods, so further research could use a period of more than three years to measure the duration of audit tenure.

\section{References:}

Ahmad, Raja Adzrin Raja, Kamarudin, Khairul Anuar. 2014. Audit Delay and Timeliness of Corporate Reporting: Malaysia Evidence. ResearchGate.

Al-Ghanem, Wafa, Hegazy, M. 2011. An Empirical Analysis of Audit Delays and Timeliness of Corporate Financial Reporting in Kuwait. Eurasian Business Review, 1, 73-90.

Anggreni, Ni Kadek Ayu Asri, and Latrini, M.Y. 2016. The Effect of Audit Tenure on the Publication of Audited Financial Reports with the Specialization of Industrial Auditors as Moderators. Accounting E-Journal of Udayana University, 15(2), 832846.

Arifa, Alvina Noor. 2013. Development of Audit Model Delay with Audit Report Lag and Total Lag. Accounting Analysis Journal.

Enofe, A.O., Aronmwan, E., Abadua, H.S. 2013. Audit Firm Rotation and Audit Report Lag in Nigeria. Journal of Business and Management, 12, 13-19.

Che-Ahmad, Ayoib, and Abidin, S. 2008. Audit Delay of Listed Companies: A Case of Malaysia. International Business Research, 1.

Dao, M., Pham, T. 2014. Audit tenure, auditor specialization and audit report lag. Managerial Auditing Journal, 29(6), 490-512, doi:10.1108/MAJ-07-2013-0906.

Dewi, Kadek Indah Kusuma, and Ratnadi, Ni Made Dwi. 2016. Company Age Influence, Tenure Audit, and Good Corporate Governance at Financial Report Publication Speed. Udayana University Accounting Journal, 15(1), 463-494.

Distianingsih, Ni Putu Julia, Tenaya, Gede Agus Indra. 2017. Auditor Specialization As Moderating the Effect of the Tenure Audit and KAP Size on the Lag Report Audit. Accounting E-Journal of Udayana University, 18(2), 1230-1258.

Fahmi, I. 2011. Analysis of Financial Statements. Bandung, Alfabeta.

Fornell, C., Larcker, D.F. 1981. Evaluating Structural Equation Models with Unobservable Variables and Measurement Error. Journal of Marketing Research, 18(1), 39-50.

Geisser, S. 1974. A Predictive Approach to the Random Effects Model. Biometrika, 61(1), 101-107.

Ghozali, I., Latan, H. 2015. Partial Least Squares Concepts, Techniques and Applications using the Smart PLS 3.0 Edition 2 Program. Yogyakarta, Badan Penerbit - Undip.

Grima, S., Seychell, S. and Bezzina, H.F. 2017. Investigating Factors Predicting Derivative Mishandling: A Sociological Perspective. European Research Studies Journal, 20(4A), 3-17.

Hapsoro, D., Suryanto, T. 2017. Consequences of Going Concern Opinion for Financial Reports of Business Firms and Capital Markets with Auditor Reputation as a Moderation Variable: An Experimental Study. European Research Studies Journal, 20(3), 3-20.

Haryani, Jumratul, Wiratmaja, I Dewa Nyoman. 2014. Effect of Company Size, Audit Committee, Implementation of International Financial Reporting Standards and Public Ownership in Audit Delay. Accounting E-Journal of Udayana University, 6(1), 63-78.

Hassan, Y.M. 2016. Determinants of audit report lag: evidence from Palestine. Journal of Accounting in Emerging Economics, 6(1), 13-32, doi:10.1108/JAEE-05-2013-0024. 
Jeva, I. and Ratnadi, Ni Made Dwi. 2015. Company Age Influence and Tenure Audit on Financial Report Publication Speed. Accounting E-Journal of Udayana University, 12(3), 530-545.

Kowanda, D., Pasaribu, Rowland Bismark Fernando and Fikriansyah. 2016. Antecedents of Audit Delay on Issuers of LQ45 on the Indonesia Stock Exchange. JRAK, 12(1).

Krisnanda, I., Gede Wahyu., Ratnadi, Ni Made Dwi. 2017. The Influence of Financial Distress, Company Age, Tenure Audit, Board of Commissioners Competency on Financial Report Publication Speed. Accounting E-Journal of Udayana University, 20(3), 1933-1960.

Kurniawan, A.I. 2015. Analysis Faktor-Faktor Yang Mempengaruhi Audit Delay (Studi Empiris Pada Perusahaan LQ 45 yang Terdaftar di Bursa Efek Indonesia Periode Tahun 2010-2013). Skripsi. Universitas Diponegoro.

Kusumah, R., Wedi, R., Daniel, M.T.H. 2016. Effect of Audit Quality, Tenure Audit on Audit Report Lags with Industrial Auditor Specialization as Moderating Variables, doi:10.13140/Rg.2.1.2304.7920

Lee, H.Y., Mande, V., Son, M. 2009. Do Lengthy Auditor Tenure and the Provision of NonAudit Services by the External Auditor Reduce Audit Report Lags? International Journal of Auditing, 13(2), 87-104, doi:10.111/j.1099-1123.2008.00406.x.

Mukhtaruddin, M., Oktarina, R., Relasari, R., Abukosim, A. 2015. Firm and Auditor Characteristics, and Audit Report Lag in Manufacturing Companies Listed on Indonesia Stock Exchange during 2008-2012. Expert Journal of Business and Management, 3, 13-26.

Narayana, Dewa G.A., Yadnyana, I.K. 2017. Effect of Ownership Structure, Financial Distress and Audit Tenure on Timeliness of Financial Report Publication. Accounting E-Journal of Udayana University, 18(3), 2085-2114.

Owusu, A. 2000. Timeliness of corporate financial reporting in emerging capital markets: empirical evidence from the Zimbabwe Stock Exchange. Accounting and Business Research, 30(3), 241-254, doi:10.1080/00014788.2000.9728939.

Pham, T., Dao, M. and Brown, V.L. 2014. Investment Opportunities and Audit Report Lags: Initial Evidenc. Accounting and Finance Research, 3 (4), 45-57, doi:10.5430/afr.v3n4p45.

Praptika, Putu, Y.H., Rasmini, N.K. 2016. Effect of Tenure Audit, Auditor Substitution, and Financial Distress on Delay Audit on Consumer Goods Companies. Accounting EJournal of Udayana University, 15(3), 2052-2081.

Puspitasari, Ketut, D., Latrini, Made, Y. 2014. Effect of Company Size, Subsidiaries, Leverage and KAP Size Against Audit Delay. Accounting E-Journal of Udayana University, 8(2), 283-299.

Ratnaningsih, Ni Made Dwita, and Dwirandra, A.A.N.B. 2016. Auditor Specialization as a Variable for Moderating the Effect of Tenure Audit and Auditor Substitution on Audit Delay ". Accounting E-Journal of Udayana University, 16(1), 18-44.

Rustiarini, Ni Wayan, and Sugiarti, Ni Wayan Mita. 2013. Effect of Auditor Characteristics, Audit Opinion, Tenure Audit, Auditor Substitution at Audit Delay. Scientific Accounting and Humanika Journal, 2(2).

Sa'adah, S. 2013. Effect of Company Size and Internal Control System on Audit Delay. Empirical Study on Manufacturing Companies Listed on the Stock Exchange. Padang Pus State University.

Stone, M. 1974. Cross-Validatory Choice and Assessment of Statistical Predictions. Journal of the Royal Statistical Society, 36(2), 111-147.

Subagyo, P. 2009. Manajemen Operasi. BPFE, Yogyakarta. 
Sudaryono, Bambang, and Sinaga, S. 2007. Factors Affecting the Timing of the Presentation of Audit Financial Statements (Empirical Study of the Existence of the Internal Audit Division in Companies Listed on the JSX). Accounting journal, 7(3), 223250.

Suryanto, T. 2014. Determinants of audit fee based on client attribute, auditor attribute, and engagement attribute to control risks and prevent fraud: A study on public accounting firms in Sumatra-Indonesia. International Journal of Economics and Business Administration, 2(3), 27-39.

Suryanto, T., Thalassinos, I.E. 2017. Cultural Ethics and Consequences in Whistle-Blowing among Professional Accountants: An Empirical Analysis. Journal of Applied Economic Sciences, 6(52), 1725-1731.

Susilawati, Christine Dwi Karya, Lidya Agustina and Tania Prameswari. 2012. Analysis of Factors Affecting the Delay of Audit in the Consumer Goods Industry Company on the Indonesia Stock Exchange (Period 2008-2010). Accurate Accounting Scientific Journal, 10, 19-30.

Yazid, H., Suryanto, T. 2016. An Investigation of Factors Influencing Audit Quality According to Islamic Audit: A Study for the Jakarta Islamic Index. International Journal of Economics and Business Administration, 4(1), 20-38.

Widati, Listyorini Wahyu, and Fina Septy. 2008. Faktor-Faktor Yang Mempengaruhi Rentang Waktu Penyajian Laporan Keuangan Ke Publik. Fokus Ekonomi (FE), 7 (3), 173-187.

Wirakusuma, Made Gede, and Manik Cindrawati, P. 2011. The Influence of Profitability, Solvability, Auditor Reputation, Company Size, Profit Content, and Type of Industry in the Inaccuracy of Financial Report Publication in the Indonesia Stock Exchange 2007-2009 Period. Jakarta.

Wiryakriyana, Anak Agung Gede, and Widhiyani, Ni Luh Sari. 2017. Effect of Company Size, Leverage, Auditor Switching, and Internal Control Systems on Audit Delay. Accounting E-Journal of Udayana University, 19(1), 771-798. 